loiur, an eputle, ace. ming. litir, 78; pl. det lettrib, 65; leitreachelbh, 81, th; 00 beitreathe, 60

mechtnedh, is; conder, ofcrow medhmughudh, 74 ; act of oovrthrowasp, rerbel moun of midmelghim

medre is; dog, medradh, 6

mlor, 24; mayor, thesurd

matghiedir, 00, mastor, meghistur, For Haster, 1590

mithen, boregh, gen. mesthin ; 66

marc-dlangh, 45 , mergllangh, 88 ; hores. hout, carcalry

meth, good, a noble; pl det. mathelbh, 2 , by.torm of matith pl nom. meithl, nobles, 82; det, meithlb, 24

mi-otilltibo, 14 ; serveles

mi-dóhes, 16 ; despayr

mi medhón in foghmeir, 84; Soptrmber; lit. 'the mid-month of the attann' mi roedhón in ghomrldh, 98 ; Decomber, lit. "the mid-month of the Fintor' middar, 78, masmpon, from Jild.-Eng. mexaget

adbre, hent; det. pl. oldhreabubh, 12 ofdhrwht, horitage, gon. oldhrechte, 54 olrbert, as, proweses

dofical, 8, prinataly, O'Don. Gr. 288

othrdil, an offering; gen. wns. othrale 19 , 45, det. otbrill, 24; a corruption of offrdil, lounded on Lat. offorr

pape $1,68,60,67,90$, pops ; nom. dael, 67 preatm, I espowen; prot ing. B do pon, 89 ; prot part peret potat 10, o4, 80; powiten 78

primb-tlloman, 68; chiof fattoul

prinne primce ; det pl. prinniadhelbh, 81 pridit, 68, grwor

prista, 47; pribon

procotbir, 88; proourator, ahisf goomor

rabodh, I2; warnirg, beter robudh reidbighim, I make mooth, elear, Ind fat sog. 9 rtidblochedh, 19

ridere, 5, of ; a kmaght; pl. det. riditibh, 24 ; gen rideredb, og; trom A.S. rideré righecht 1, 04, ktrashy

ro-ohrodhe, $\delta$; orry hardy

ro-douligh, 5 ; rery stern

cenghdestr, capitlarits, sen pl., 60, 71

ma-ehatilén, 52 , an ald fortateon

colrbbit, (divinc) wrouce ; gen colrbist, of coletbuah, 89 , thorny

Hobher, 5, 19, 85, 7t; Eridher, 12 , mure, 0 Fr. escouy

sthetghim, I rake peace (odb) ; prot. ving. 8 do stdheigh, 58

mechtecbedh, 66, act of moring, wr. oustrg athority (monht)

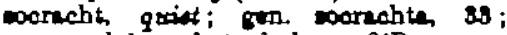
cocrachd, unditisubedinas, O'R

wdh (akgh ?), prouperity; gen. widb (leg vigh ?), \&s; abb, propority, good cheor, $\mathrm{O}^{\prime} \mathrm{Br}$.

eporaim, I sptur, prot ulng. 8 do por, 69 ; donom. of opor, epar, and this trom A.8 spora, optra

stert, steld, s4, statuts

tabhertull, 48, 49, 07, donatrow, grant

tereainno, 48, disparagrment

toioce, 11 ; realth

towe, 7 ; at axpedetion, tolug O'Don. Gr. $B$ trenbhedh menmen, to, lik." hasbend. ing of upirith' weom here to meen arrogarice

trolehthesoh (trom traithoob), fookwoldier, pl. gen, 5 ; nco. trolohthwabe, 48

tderese, o5, atshority; derit of eldar, 42 ; better tiphdar; borrowed trom Lit attator

dlinb, rady; compar. thllme, 87,0 . Ir. allam

umhle, 40, 00, 81 homage, ov sing, 60 urrante, 87 , 'bold, daring, daumilos,' $O$ 'B.

\title{
The First Recorded English Voyage to the West Indies.
}

Oriedo, the offlcial historian of the Indies, in bis nineteenth book, published in 1535, narrates the visit of an English ship to Santo Domingo in 1527 (lib. rix cap. 13). Herrera in his history, published in 1601, gives a different and much fuller account of the seme event, which he assigns to the year 1619 (dec. ii. lib. v. cap. 3). Mr. Biddle in his Memonr of Sebastian Cabot (1881) and Professor Arber in the introduction to the First Three Englush Books on America accept Oviedo's date, bat regard Herrera's narrative as more accurate; and both these English writer identify the English ship with the 'Mary of Guildford,' which asiled from the Thames on 20 May 1627 in company with the 'Sameon,' left Plymouth on 10 June, lost her consort in a storm on the night of $1 \mathrm{July}$, 
entered St. John's harbour, Newfoundland, on 8 August, and, according to Hakluyt's informents, returned to England about the beginning of October. ${ }^{1}$

There is an a prori difficulty about this identification. If the 'Mary of Guildford' returned from Newfoundland without freah ed ventares, it is not very otrange that her homeward voyege should have been left unrecorded, so that we hear nothing of her between 10 Angust 1527 (on which date one of her company, Albert de Prato, wrote to Woley' from St. John's, Nerfoundland) and the beginning of October, when ahe reached England. But if she visited the West Indies on her homemard royage, was fired upon from the castle of Santo Domingo, bertered with the Speniards in Puerto Rico, and then got safe home with the news, it is very strange that there ahould be no record of such novel and erciting adventares of a king's ship. Hall in recording their departure says : 'If they speed well you shall heere of their return.' He would sarely have redeemed thin conditional promise if the isene of the voyage had been 80 remarkable.

A solution of the difficulty is saggested by a Spanish document earlier than Oviedo : this is a despatch eent from Puerto Rico to Bento Domingo immediately after the first appearance of the English ship. The greater part of Herrera's narrative is an inaccarste abridgment of this document. Both on account of this inaccuracy and on account of ane chronological and linguistic difficulties it seems beet to give this contemporary account of the first English voyage to the Wegt Indies in the original Spenish, as it appears in the thirty-serenth volume of the Documentos inditos relativas a las Pasesiones Espanolas en Ambrica.

\section{Relaoion de una ndo ynglesa questobo on la Ysla de La Mona o yda para La Espariola.}

Bunoto Damingo: Noviambre $19 \mathrm{de} 1528$.

Estando el Marteo pasado, que se contaron diez e nueve dies derto presente mes do Noviombre, cargendo la Oaravele de Oacobe, allegó une né de dusclentos e cinonente toneles de porte, de tres gevias, y areyendo quere náo Despara salió con on betel it alle, e ellos selioron con ana pinsen que trejen, que bogebe veinte a cinoo o treinta remos, $J$ renien on elle teste veinte e cinco ombres con el Mrestro do Le diche nito, el qual venie por Maestre e Gepitan, a todos venien armedos de correletes a

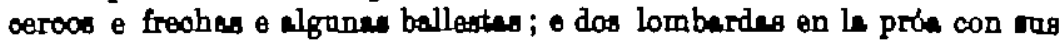

' Hall, Chrowich, enno 1627 ; Parohes, Puprina, rol ill p. 108; Hatlagt, rol ill.

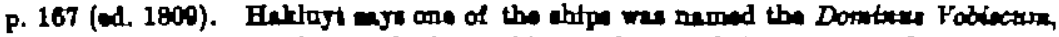
bat there on bo no doabt thet be is apmeting of the axpeditton mentioned by Grafton

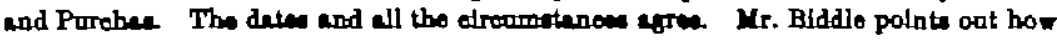
endly the crror of neme may here ertem; bat we need not oren ruppost any orror, for the ahtp mey here changed ber neme, life Drake's 'Pelioen.'

Parchere, boc. eft. 
moohera encendidas; los quales llegadow ó ollos, el les pregunto de qué tierre eran, e dixeronle queran jngleses de dentro do lo Cibded de Londres, e que la néo ar del Rey de Ynglaterre preguntéles que venían s buscar en otes partes, dixéron, quel Roy abis armedo equalle NLo, e otre para yr a deecobrir la tierra dal gran Oan, e que jendo lea

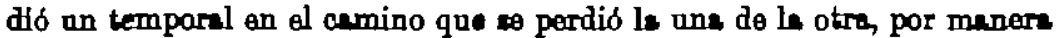
que nunoe más la abien visto; a quellos gygrieron gu viexe o dieron en un Max eledo, e que falleban goles grandes de jelo, e non podiendo por elles pacar, tomaron otre derrote e dieron on otro Mar caliento, como uns calders quando 1 erve con stas; e por miedo que aquel agus non les derretice la pex de lo abo, se volviaron e vynieron a reconoscer a los vasellos, donde falleron bien oinquents neós castellenes $\theta$ franoesen $\theta$ portugueser, percando, eque alli sojeron salir en tierre por tomar lengue de loe yodios, $\theta$ liendo en tierre les materon low yndio al Piloto, el qual dixeron quera piamontés de neoion; y de alll pertieron e vymieron la Coste de ls tierra Nueva, donde fué a pobler Ayllon, quetruscientes legass, o mós de alll; atraveseron y vynieron a reconosoer a este Yéls de Bent Xoan; I preguntídoles que qué banosban en esters yales, diréron que querien ver estas relas pare der rason dellas el Rey de Ynglaterre, e viotes, carger de bracil, y volverso. E pregantaron por la derrota do Sanoto Domingo, e parn el puerto, e quí́n gobernaba la Yale, que querien yr allá a valle, $\theta$ w lo dxro todo. Ellos lo posioron por memoria, $\theta$ el Mrestre de la néo juglese rogó a Xinós Navarro que fueve e ver su néo, el qual fá́ $\theta$ le vido tode, $\theta$ que non train en olls otre cose sinon vino $\theta$

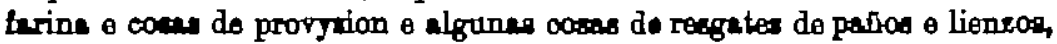
e otra cousa e munoha sityllaria e buena; o que traen carpintoros

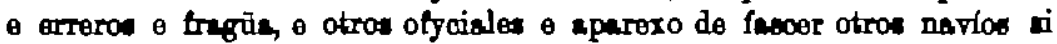
tobiewen dello necesided; $\theta$ an orno donde onezen pan; $\theta$ que tod la xente quen le náo sbin, prien fuste pesenta persones. Disoe quel Meastro do la néo preguntó, si mbin loer en latin ó en Romenco; porque le querie mowar le jntencion que trais del Rey de Yngletarre, e como non eabia leer non la vido; e quel Meestre e faste e vainte o cinco o trainta ombres alieron on tierre a La Mona, e extobleron allí fasto el Miérooles en la tardo; $\theta$ salieron todos armedos, que sombarcaron para Sancto Domingo; e quel Xreves de mentene, tirando dos tiros de lombarde $\theta$ toosendo une trompota bestarda que trafen, se tyscieron a lo vele $e$ fueron la fis de Sancto Domingo, farte que los perdieron de viste, $\theta$ el dicho Xiné Nevarro estobo en La Mona, fast el Vfernes que we vino a este Yale.

Esto treeledo woo del oroxinal que se ymbró a Real Abdyencie,

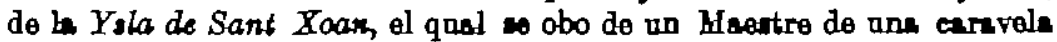
queabe en La Ysla do la Mona al tiempo que la náo juglesa pasó por allí de ceminar pare Puerto de Sanoto Domingo. Diego Oabalco.

This docament, translated into English, runs as follows:-

\section{Accotht of an English Ship which virited the Island of La Mona (Honkey Island) and departod for La Espanola.}

Bancto Damln:so: November 19, 1628.

On Tuesday last, the nineteenth day of this present month of

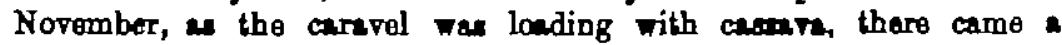
abip of 250 tons burden, of three masts, and thinking that it was a abip 
of Spein he rent out in hil bout to her; and they put out wnth 2 pinnece whloh they had with them, which wes roved by trenty-five or thirty ans, and there came in the pinnece about twenty-five men with the menter of the sajd ship, who came as manter and captain, and all the men came armed with contets and shields and arrows and some cross. bows, and two lombards in the prow with their metches kundled; and when they met he esked them of phat country they were; and they asid thet they were English from within the eity of London, and thet the thip was of the king of England. I anked them what they came to in these perts they asid that the hing hed fitted out this shup and another to go and diecover the land of the great Khan, and that as they went a storm fell upon them in the way, that one (ohip) was lost to the other, wo thet they never saw her afain; and that they parsued their ropage and eame to a frozen sees and found great islends of $i c e$, and not being eble to pass by them they took another direction and came to enother sea (whroh wes) hot, like a kettle when it boils with water; and for fear lest that water nhould malt the pitch of their ship they turned about and rent to explore Los Beccaleos (the ood-fishery ooventa), where they found fall fifty ships, Castilian, Portuguese, and French, flshing; and that there they proceded to land in order to have speech of the Indiens, and es they lended the Indiens killed their pilot, ${ }^{4}$ who they said wes Piedmonte by nation; and they departed from there and came (along) ${ }^{s}$ the coent of Le Tierr Nueve (1.e. the east const of North America), where Ayllon ' went to oolonier, four hundred leegues and more; ' from there they aroesed orer end came to explore this alend of Sun Juan (1.e. Paerto Rioo); and when it pas asked them what they sought in these ialands they said that they desced to seo there ielands in order to give an coount of them to the kng of Eingland, and efter seang them to lowd with brasil rood and retarn. And they asted for the direction of Santo Domingo, and for the port, and who was governor of the 18 land, for they desed to go thither to it, and everything ras told to them. They took note of it, and the mester of the Englinh ship esked Gines Naverro to go and bis ship, and ho went and aw all the wip, and thet be (the Englishmen) carried in her nothing bat wine and flour end mattorn of provision and some artieles for barter of cloth and linen, and other thingz, and much good artallery, and that they carry oarpentors and smiths and a forge, and other workmen end epperntus to malre other ahipe if they ahould heve need of them; and an oven phere they bate

- Thle detefl eqrow oth Hell, who ars. 'Tho hing went two fajre shlpe, wed manned end well ritajled, haring in them divers conning mem, to reste trange

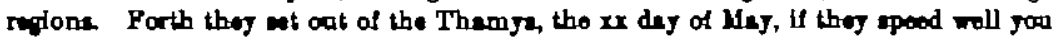
ahall hoore at thelr retarna.'

- Mr Bldde thinke this wes the femone Florentino Vorarmeno, who on his lest

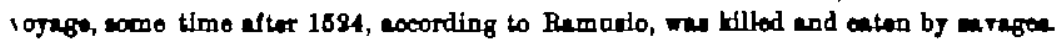
Mr. J. W. Jones, in his edition of Belluyt's Dreers Forages, show that the Identiscation is improbeble (Heklayt Boo. Publtetiona).

- I read 'por la conte.'

- The liowntete Veaquez de Afllon mado a royago of dicoovery to 'Floride' in

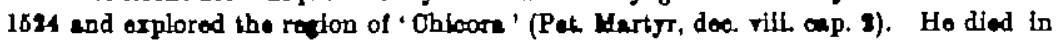
Oetober 1528 in the courno of en ettempt to plent a colony on the North Amencen const (Winsor, Crilxeal and Narration Hittory, rol. u).

- This in en obriogs correctran of the punetuation. 
bread; and thet all the men who were in the whip would be sbout sixty persons. He eays that the mester of the ship ested him whether bo conld read Latin or Spaninh, becente be desired to ahow him the decign (instruction ?) which he carned from the hing of Englend; and ance he mew not bow to read he did not 100 it; and that the master and about five-end-twenty or thithy men lended on La Mons, and remeined there tall Wedneeday in the afternoon; and they all went out (or lended) armed," thet they embarted for Banto Domingo; and that on Thuredey in the morning, firng two shots of a lombard end playing on a bestard trumpet which they had rith them, they set sail and went in the direction of Sinto Domingo, until they loet them from sight, and the mid Gune Nevarro remeined at La Mone till Fridey, when he arme to this islend (i.e. Puerto Rico).

The copy was taken from the original, which was sent to this Royel Audienoe (of Sento Domingo) from the island of San Jann (Puerto Rioo), whioh original wa hed from (the month of) a mester of a caravel which was at the islend of La Mons at the time when the English ship rent thither on its way to this port of Sento Domingo.

Diggo Oaballo.

Notwithstanding the crooked grammar and the queer changes of person and tense, this docament, if carefully examined, explains itself. I interpret it as follows: Ginés Nevarro, an illiterate skipper, was taking cargo on Tuesday, 19 Nov. 1587, at the island of La Mona (Monkey Island), situstod between Puerto Rico and La Espantola, when an English ship arrived and stayed till Tharsday the 21st, on which date he sailed for Bento Domingo. On Friday the 22nd Navarro asjled to Puerto Ruco and related all that he had sean and heard. Bome official not very akilful with the pen wrote down his story, apparently almost in Navarro's own words, but with oome gremmatical confusion, Navarro appesing first as he, then as I, and lastly as Gines Navarto. The story is told not in the order which would be most luoid to the reader, but in the order most natural to the speaker : having just arrived from La Mona, he thinks it saperfluous to mention that place, and he begins with the matter which is most important to him : ' the caravel wes loading with cassara.' The document go written in Puerto Rico wes sent, undated, to Santo Domingo : a copy of it was there made by Diego Ceballo, and this copy was sent, also unduted, to Spain. The official who recelved it in Spain seme to have inserted the date, taking the vords Noviembre 19 from the first line of the letter and adding the ourrent year in which the letter reached Bpain, 1588. It must be remembered that in Spanish despetches of that time the date is asually given not separately at the beginning, bat in the body of the document at the end. If Nomembre 19 do 1528 is the genuine date of the copy made at Santo Domingo, then this copy was made for despatch to Spain exactly a year after the

- Thero is come confunion or antesion hero. 